\title{
The Role of Religiosity on Work-Family Conflict, Work- Family Enrichment and Well-Being among Muslim Women Academicians in Malaysia
}

Nurul Nadia Abd Aziz, Zaidatul Nadiah Abu Yazid, Nor Habibah Tarmuji, Mawarti Ashik Samsudin, Azeman Abd Majid

To Link this Article: http://dx.doi.org/10.6007/IJARBSS/v11-i3/8807 DOI:10.6007/IJARBSS/v11-i3/8807

Received: 17 January 2021, Revised: 20 February 2021, Accepted: 01 March 2021

Published Online: 16 March 2021

In-Text Citation: (Aziz et al., 2021)

To Cite this Article: Aziz, N. N. A., Yazid, Z. N. A., Tarmuji, N. H., Samsudin, M. A., \& Majid, A. A. (2021). The Role of Religiosity on Work-Family Conflict, Work-Family Enrichment and Well-Being among Muslim Women Academicians in Malaysia. International Journal of Academic Research in Business and Social Sciences, 11(3), 472-497.

Copyright: (c) 2021 The Author(s)

Published by Human Resource Management Academic Research Society (www.hrmars.com)

This article is published under the Creative Commons Attribution (CC BY 4.0) license. Anyone may reproduce, distribute, translate and create derivative works of this article (for both commercial and non-commercial purposes), subject to full attribution to the original publication and authors. The full terms of this license may be seen at: http://creativecommons.org/licences/by/4.0/legalcode

Vol. 11, No. 3, 2021, Pg. 472 - 497

Full Terms \& Conditions of access and use can be found at http://hrmars.com/index.php/pages/detail/publication-ethics 


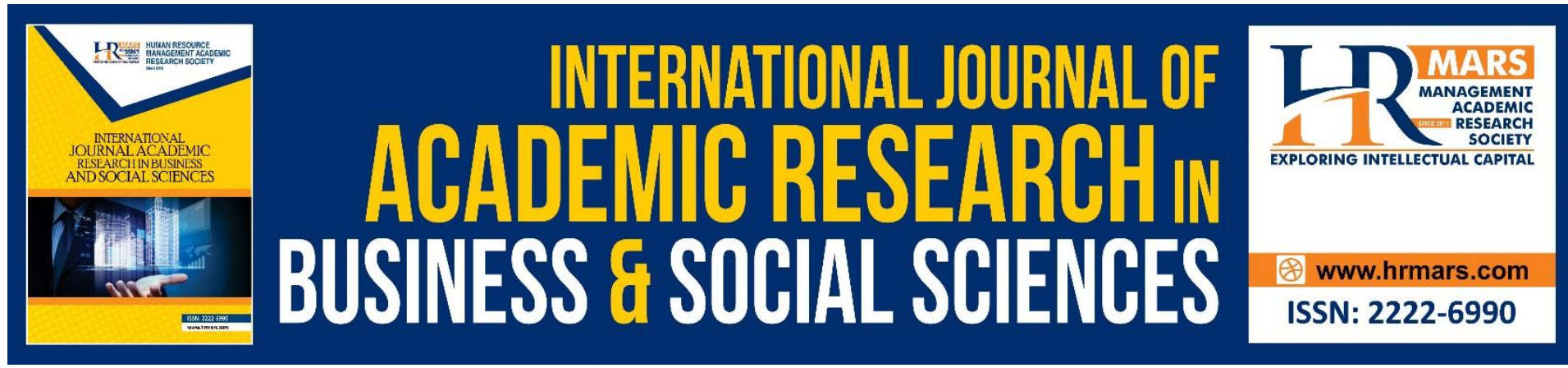

\title{
The Role of Religiosity on Work-Family Conflict, Work-Family Enrichment and Well-Being among Muslim Women Academicians in Malaysia
}

\author{
Nurul Nadia Abd Aziz ${ }^{a}$, Zaidatul Nadiah Abu Yazid ${ }^{b}$, Nor \\ Habibah Tarmujic, Mawarti Ashik Samsudin', Azeman Abd \\ Majide.
}

a, baculty of Business and Management, Universiti Teknologi MARA Pahang (Raub Campus), Pahang, Malaysia, ${ }^{\mathrm{C}}$ Faculty of Computer \& Mathematical Sciences,Universiti Teknologi MARA

Pahang (Jengka Campus), Pahang, Malaysia, d, eFaculty of Business and Management, Universiti Teknologi MARA Pahang (Jengka Campus), Pahang, Malaysia.

\begin{abstract}
Over the last few decades, the issues of work-family conflict, work-family enrichment, and well-being have been widely discussed in the literature. Nevertheless, most studies focus more on examining different types of coping strategies in dealing with conflict as well as those that improve well-being. This study aims to examine the mediating roles of religiosity on the relationships between work-family conflict, work-family enrichment, and well-being. The body of data used in this research was gathered from 140 Muslim women academicians at Universiti Teknologi MARA. The analytical evaluation was conducted using SEM-AMOS 21.0. The relationships between well-being, work-family conflict, work-family enrichment, and religiosity were found to be significant. The key findings of this study are religiosity fully mediates the association between work-family conflict and well-being, and partially mediates the relationship between work-family enrichment and well-being. Since most of the researchers often test religiosity as an independent variable in influencing well-being, the findings of this study are expected to bridge the gap by providing empirical support that religiosity could act as a mediator in the relationships between work-family conflict and workfamily enrichment on well-being. The originality of this study may contribute to the formation of a new body of knowledge, and enrich the literature sources in the field of work-family conflict, work-family enrichment, and well-being that will benefit the academicians.
\end{abstract}

Keywords: Muslim Women Academicians, Religiosity, Well-Being, Work-Family Conflict, Work-Family Enrichment.

\section{Introduction}

In general, women traditionally resume the role of homemakers and child caretakers (Aryee, Luk, Leung, \& Lo, 1999; Grönlund \& Öun, 2018; Halim, Aziz \& Samsudin, 2016; Jones, Teel, Martinez, \& Solomon, 2020; Raffenaud, Unruh, Fottler, Liu, \& Andrews, 2020; Roman, 2019) while men continue to play the role of primary breadwinner of the family (Treas, Lippe, 
\& ChloeTai, 2011). Despite women having a professional career and have achieved much success, they still strive to fulfil their household chores responsibilities (Noor, 2008; Tafvelin, Keisu, \& Kvist, 2020). As more and more married women enter the labour force, the literature has expressed concern about how women cope with their multiple social roles as a wife, mother, and worker. Many studies have been conducted to investigate the issue of women's well-being as women are seen to face constant struggles in achieving well-being due to the difficulty in balancing the demands of paid work and domestic tasks (Aziz et al., 2016, 2018; Noor, 2010; Phipps \& Prieto, 2016; Raskin, 2006; Roman, 2019; Tafvelin et al., 2020; van der Lippe et al., 2006; van Steenbergen et al., 2007; Zahra \& Simin, 2011).

In the Malaysian context, it is found that in the first quarter of 2020, a total of 5.95 million (39 per cent) from 15.24 million employed people in Malaysia are women (Department of Statistics Malaysia, 2020). From this figure, approximately 70 per cent of working women are married or have families of their own (Achour, Nor \& Yusoff, 2015), with multiple roles proven to be challenging and impactful to their well-being. The present study is to extend the previous research (Aziz et al., 2018), which investigates the well-being of Muslim women academicians in a public university in Malaysia. According to Jacobs and Winslow (1998), due to institutional demands and accountability, it is a common practice for academicians in most Malaysian universities to have a work intensification of 50 or 60 hours a week. Work and family demands make academic work more challenging in terms of time and effort (Fakhrorazi et al., 2019; Gewinner, 2019). This is the most critical barriers to career development for women academicians in Malaysia (Achour et al., 2014). Due to these factors, this target group is considered as vulnerable to impaired well-being. The current study focuses on the ability of Muslim women academicians to manage conflict between work and family demands and their ability to take advantage of enrichment from both domains.

Although many studies have shown that work-family conflict can have a significant and direct impact on well-being (Aazami et al., 2015; Ahmad, 1996; Aziz et al., 2018; Koyuncu et al., 2012; Rasheed et al., 2018; van Steenbergen et al., 2007), few studies have been conducted to study on how to resolve conflicts between these domains in order to improve women's well-being. Some researchers (Aziz et al., 2018; Krok et al., 2019) prove that coping strategies might act as a mediator between work-family conflict and well-being. According to Lazarus (1999), a coping strategy is suggested to operate as a mediator of emotional outcomes from stressful encounters because the nature of coping engaged in responding to different threats and having different implications for outcomes. The variables that have been used as coping strategies in dealing with work-family conflicts are mental adjustment (Lexshimi et al., 2014), planning and acceptance (Qiao et al., 2011), and sources of social support from organisations, supervisors, families, spouse, and others (Bromer \& Henly, 2009; Leung et al., 2020; Matthews et al., 2010; Nwagbara, 2020; Peeters et al., 2009; Seiger \& Wiese, 2009; van Daalen et al., 2006; Voydanoff, 2004).

Nevertheless, very little attention is given to religiosity that may also play a role in resolving conflicts, thus affecting well-being. Religiosity is often used as an independent variable in influencing well-being (Hassan, Dollard, \& Winefield, 2010; Imam et al., 2009; Momtaz et al., 010). However, if religiosity is seen as one of the essential coping strategies (Achour et al., 2014; Achour et al., 2015; Kaliampos \& Roussi, 2017), then it would be able to serve as a mediator between work-family conflict and well-being. This proposition is 
underlined by several researchers (Noor, 2008; Unterrainer et al., 2014) who highlighted that religiosity is an essential element in the healing process from mental illness and are able to protect individuals from addictive or suicidal behaviour. Furthermore, a few researchers (Achour et al., 2014; Achour et al., 2015) suggest religiosity as a coping strategy to solve life's problems, and as a means to improve well-being. Thus, it is reasonable to admit that religiosity is one of the coping abilities that may ultimately affect well-being. Therefore, this study attempts to examine the mediating role of religiosity in the relationship between workfamily conflict and well-being.

Besides work-family conflict, several studies have also found that work-family enrichment has a significant impact on women's well-being (Aazami et al., 2015; Ahmad, 1996; Aziz et al., 2018; Gözü et al., 2015; Koyuncu et al., 2012; Rasheed et al., 2018; van Steenbergen et al., 2007). Nonetheless, empirical evidence has presented that work-family enrichment may also be related to negative indicators of well-being, such as depression or burnout (Innstrand, Langballe, Espnes, Falkum, and Aasland, 2008), psychological strain (Kallaith, 2014), and on job strain (Barbic et al., 2017). Notwithstanding numerous studies that have discovered a significant relationship between work-family enrichment and well-being, there are still relatively few studies that have examined the simultaneous impact of both work-family conflict and work-family enrichment on well-being, particularly in the context of Malaysian Muslim women academicians.

In addition, past researches have shown that both work-family enrichment (Culbertson et al., 2012; van Steenbergen et al., 2007) and religiosity (Achour et al., 2015; Achour et al., 2017; Imam et al., 2009; Momtaz, Hamid, \& Yahaya, 2009; Momtaz et al., 2010; Rakrachakarn et al., 2013) are positively related to well-being. Moreover, several past researches (Achour et al., 2014; Achour et al., 2015; Sim \& Bujang, 2012) have also revealed that work-family enrichment and religiosity are positively correlated. Accordingly, instead of merely assuming that work-family enrichment has only the direct influence on well-being, the indirect effects, i.e. the mediator effects through religiosity may take place as well. This means that the relationships between work-family enrichment, religiosity, and well-being could be more complex and might consist of intermediate interactions such as the mediating effects, thus warrant further examination. For that reason, the other purpose of this study is to examine whether religiosity mediates the work-family enrichment and well-being relationship, particularly in the context of Malaysian Muslim women academicians.

\section{Objectives}

This research aims:

- To determine the relationship between work-family conflict and well-being.

- To determine the relationship between work-family enrichment and well-being.

- To examine the mediation effect of religiosity on the relationship between work-family conflict and well-being.

- To examine the mediation effect of religiosity on the relationship between work-family enrichment and well-being.

\section{Literature Review}

Research by Koyuncu et al. (2012) discovers that a higher level of work-family conflict was linked to lower levels of psychological health and less favourable work outcomes. 
Additionally, according to Hofäcker and König (2013), the irregular and unpredictable working hours and condition would cause conflict when the individual was trying to coordinate his or her work and family demands. It has been underlined in previous studies (Santos \& CabralCardoso, 2008; Zahra \& Simin, 2011) that women academicians faced considerable difficulties in reconciling work and family, which consequently disrupted their well-being. Similar findings were also reported in the previous study (Aziz et al., 2018) where results revealed that Muslim women academicians who had a conflict between their work and family demands would experience impaired well-being. In this regard, we predict that the higher the work-family conflict, the lower the well-being of Muslim women academicians. Taken together, we formulate it in our first hypothesis:

Hypothesis 1: Work-family conflict has a significant negative effect on Muslim women academicians' well-being.

Work-family enrichment refers to the process in which the experience or resources from the work domain leads individuals to enhance the value of personal resources in the family domain (Greenhaus \& Powell, 2006). This domain is underpinned by enhancement theory, which explains that involvement in various roles promotes well-being and is synergistic for an individual (Allis \& O'Driscoll, 2008). Satisfactory on inter-domain roles can be positively associated with individual well-being as it reduces conflict and stress between domains (Greenhaus \& Powell, 2006). According to Culbertson et al. (2012), when a worker has positive experiences in one domain (for example at work), the positive emotions and experiences that come from that domain may provide valuable resources for that person that may facilitate optimal functioning in another domain (for example at home). It has also been claimed in other work (Fung et al., 2014) that work-family enrichment denotes work-family enhancement, facilitation, and positive spill-over. Work-family enrichment has been found to contribute to important outcomes such as satisfaction (Carlson et al., 2014; Choi \& Kim, 2012; Wiese \& Salmela-Aro, 2008), job performance (Choi \& Kim, 2012; Osman M. Karatepe \& Bekteshi, 2008; van Steenbergen et al., 2007), affective commitment (O. M. Karatepe \& Magaji, 2008; van Steenbergen et al., 2007) and well-being (Gözü et al., 2015). As such, we expect that the higher the work-family enrichment, the higher the well-being of Muslim women academicians in Malaysia. Thus, we establish our second hypothesis:

Hypothesis 2: Work-family enrichment has a significant positive effect on Muslim women academicians' well-being.

In Malaysia, Islam is the most widely professed religion with 60.4 per cent of the population, followed by Buddhism (19.2\%), Christianity (9.1\%), Hinduism (6.3\%) and Confucianism / Taoism / other traditional Chinese religion (2.6\%) (Htut et al., 2007). Religion is believed to play a vital role in the life and thoughts of an individual, who could influence how they live and experience life, affecting the purpose of life, motivation, and satisfaction with life. In the present study, religiosity refers to the beliefs, practices, attitudes, values, and traditions that are usually associated with one's religious expression and experience (Harris, 2001). A Muslim, who performs prayers, fasts, pays alms, recites the Holy Quran, practices zikr (remembrance of God), makes supplications ( $\left.d u^{\prime} a\right)$, possesses patience, forgiveness, gratitude to God, and trust in the providence of God is often considered as a good Muslim (Achour et al., 2016). Allah always reminds in Quran: 
"Such are on true guidance from their Lord; such are the truly successful" (Quran 2:5).

"So those who believe (in the message of the Truth) and do good are destined for happiness and a blissful end" (Quran 13:29)

These verses in the sacred Holy Quran teach its believers to hold on to religious principles firmly to achieve well-being as Islam is regarded as a comprehensive way of life. Several researchers found that religiosity is significantly associated with well-being. A study of Achour et al. (2015) highlights the importance of religiosity in reducing job strain and obtaining the well-being of Muslim employees. Zotti, Speziale, and Barra (2016) purported that people who share the same religious affiliations are probably more satisfied with their lives due to the intimate social network that is constructed through the frequent religious activities that they attend together. Hence, their findings suggest that social networks and intense religiosity (for example, taking part in religious activities) can be the main contributor to life satisfaction and balanced well-being. Results of another study (Abdel-Khalek, 2012; 2019) posit that there is a significant and positive correlation between religiosity and subjective well-being among Muslim Kuwaiti. Similarly, the most recent study (Villani et al., 2019) finds the role of religiosity in achieving subjective well-being. Based on the verses in the sacred Holy Quran and past research on religiosity and well-being, it is postulate that the higher the religiosity, the higher the well-being of women academicians in Malaysia; hence the following hypothesis:

Hypothesis 3: Religiosity has a significant positive effect on Muslim women academician's well- being.

There have been several studies that highlight the need for coping strategies in balancing work-family conflicts with individual well-being. Some of the coping strategies that are commonly studied include support from organisations, supervisors, families, spouse, and others (Bromer \& Henly, 2009; Leung et al., 2020; Matthews et al., 2010; Nwagbara, 2020; Peeters et al., 2009; Seiger \& Wiese, 2009; van Daalen et al., 2006; Voydanoff, 2004). Nevertheless, it is observed that the discussion of religiosity as a coping strategy in balancing work-family conflicts and well-being has been very limited. Many researchers have proposed that religiosity can be used as a remedial tool for coping with problems in one's life (Achour et al., 2014; Noor, 2010; Tan et al., 2017). The Holy Quran also describes ways in which human beings can find peace of heart from any kind of anxiety.

"Such are the ones who believe (in the message of the Prophet) and whose hearts find rest in the remembrance of Allah. Surely in Allah's remembrance do hearts find rest" (Quran 13:28)

The verse above implies that prayer, making supplications ( $d u^{\prime} a$ ), and zikr (remembrance of God), can help one feel at ease. Another verse that suggests believers to turn to the Almighty God for help is;

"Believers! Seek help in patience and prayer; Allah is with those that are patient" (Quran 2:153) 
From the above verse, Islam teaches the believers to do two things while seeking for strength to embrace life difficulties; they need to develop patience and perform prayers. Thereby, religious coping strategies refer to the tendency of a human being to turn to their religions by praying when they are faced with any problems or stress (Carver, Scheier, and Weintraub, 1989). Also, it has been noted that religious coping styles allow individuals to cope with the work conflict in a less harmful and gentler manner (Park, 2005). According to Krause, Shaw and Liang (2011), Christians build their social networks and support systems by attending church. In some ways, they can create a sense of belonging for better physical and mental health; the "social bonds" that Holmes and Kim-Spoon (2016) claim could lead to emotionally happy lives. The research done by Pramesona and Taneepanichskul (2018) finds that Qur'anic recital listening could have a positive effect on relieving depression symptoms and improving quality of life among Indonesian elderly in nursing homes. Moreover, a study conducted by Momtaz, Ibrahim, Hamid and Yahaya (2010) proves that the effect of widowhood on psychological well-being is mediated by personal religiosity.

Some researchers suggest that the effect of religiosity on work and family should be examined more closely (Hassan et al., 2010). Since previous researchers have proved that religiosity is the most salient coping strategy (Achour et al., 2014; Achour, 2015; Momtaz et al., 2010; Noor, 2010); in which some other researchers suggest that coping may serve as a mediator that can reduce the amount of stress, and improve the individual's well-being (Aziz et al., 2018; Lazarus, 1999); thus we propose that religiosity could function as a mediator of the relationships between work-family conflict and well-being. Following from the above argument and the verses of the Holy Quran, it is predicted that high levels of conflict between work and family domains will be associated with higher religiosity, which in turn will be related to high well-being. This leads us to our fourth hypothesis:

Hypothesis 4: Religiosity mediates the relationship between work-family conflict and Muslim women academicians' well-being.

Since this study attempts to examine the simultaneous effects of work-family conflict and work-family enrichment on well-being, as well as to examine the indirect effects of workfamily conflict on well-being through religiosity, thus, this study will also test the mediation effects of religiosity on the relationship between work-family enrichment and well-being. The most likely argument for this test is that the teaching of Islam teaches its believers to be grateful when it comes to favours; as such being able to enjoy the benefits of the work and family domains is a blessing for women academicians to be thankful for. According to Islamic teachings, the greater blessings that humans get, the more they should show gratitude to the favours of God towards them; they can then enjoy long-lived well-being. This can be further understood based on the Quranic verses as follows:

"Also call to mind when your Lord proclaimed: "If you give thanks, I will certainly grant you more; but if you are ungrateful for My favours, My chastisement is terrible" (Quran 14:7).

The Quran repeatedly highlights the significance of having gratitude. For instance, it is said; 
"We bestowed wisdom upon Luqman, (enjoining): "Give thanks to Allah." Whoso gives thanks to Allah, does so to his good. And whoso disbelieves (let him know that) Allah is All-Sufficient, Immensely Praiseworthy" (Quran 31:12).

Again, God says;

"And he who had some knowledge of the Book said: "I will bring it before the twinkling of your eye". When Solomon saw the throne placed firmly beside him, he cried out: "This is by the grace of my Lord so that He may test me whether I give thanks for (His Bounty) or act with ingratitude. Whoever is grateful is so to his good; and whoever is ungrateful, let him know that my Lord is Immensely Resourceful, Most Bountiful" (Quran 27: 40).

These verses of the Quran convey the same essence as a Muslim, the more we enjoy the enrichment of work and family, the more we need to be grateful for the favour of God as it will make our lives more prosperous. The use of religiosity as a mediator to investigate these relationships is still lacking in the existing literature. We expect that high levels of work-family enrichment will be associated with higher religiosity, which ultimately will be related to high well-being. The following hypothesis was investigated:

Hypothesis 5: Religiosity mediates the relationship between work-family enrichment and Muslim women academicians' well-being.

\section{Methodology}

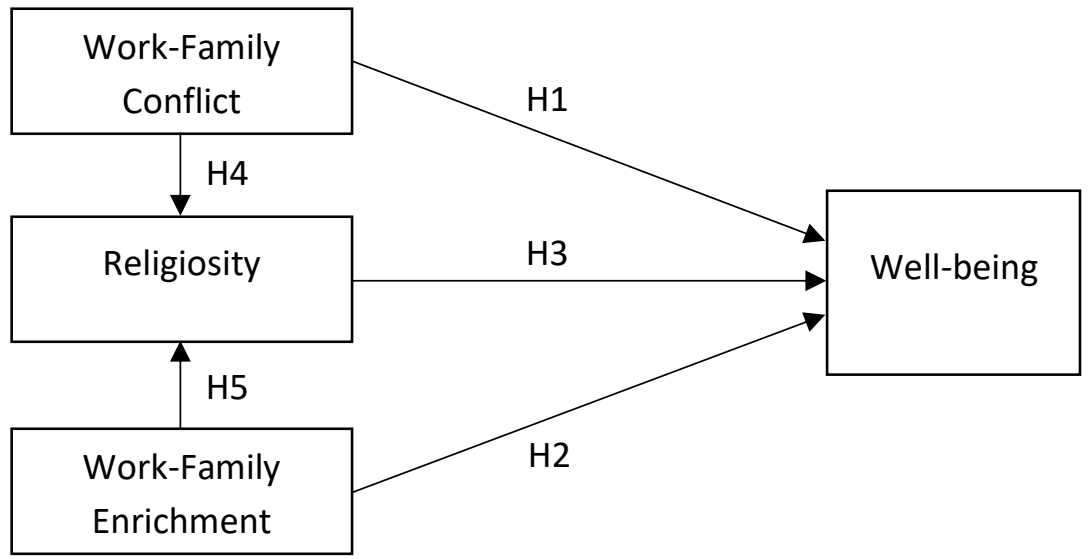

Figure 1: Conceptual Framework

This research highlights four constructs, namely work-family conflict, work-family enrichment, well-being, and religiosity, that can be understood within the framework as illustrated above. The present research intends to identify the significant effect of work-family conflict, work-family enrichment and religiosity on Muslim women academicians' well-being $(\mathrm{H} 1, \mathrm{H} 2$ and $\mathrm{H} 3)$. Also, the paper proceeds with investigating the significant effect of both work-family conflict and work-family enrichment on well-being with religiosity playing the role of a mediator ( $\mathrm{H} 4$ and $\mathrm{H} 5$ ).

In this study, the researchers selected Muslim women academicians in a public university in Malaysia as respondents. Specifically, the data for the present research was 
acquired from Muslim women academicians who work at Universiti Teknologi MARA (UiTM) in two Pahang campuses. It should be noted that 99 percent of the academicians at this university are Muslims. The respondents of Muslim women academicians represents a group of professionals with an excellent education background who have much more workloads in comparison to academic employees at other Malaysian public universities. With regard to the methodology, questionnaires were developed and distributed to the target group, i.e., female lecturers in two branches of UiTM in Pahang, namely Jengka and Raub campuses. A total of 140 Muslim women academicians were randomly selected to be the respondents of this study and all the respondents have returned their questionnaires. The sample used in this study was sufficient to fulfil the minimum requirement of the sample size to enable an effective data analysis using the Structural Equation Modelling (SEM) that was developed by (Awang, Lim \& Zainudin, 2018). Additionally, an online calculator based on Cohen's work (1988) was also employed where a comprehensive guideline was provided concerning ways of utilising the relevant variables to choose the minimum necessary sample size which is 80 per cent for social science research.

The questionnaire being used in the current study has proven to be reliable and valid as it was adopted from our previous researches (Aziz et al., 2018). It comprises 34 elements, measuring four variables and 20 questions on demographic factors. It must be highlighted that work-family conflict (WFC), work-family enrichment (WFE), and religiosity (RP) were quantified in 27 elements designed in a brief statement in addition to a ten-point Likert's scale in which answers ranged from "never" (1) to "always" (10). Also, well-being (WB) was measured using seven elements of brief statements in addition to the ten-point Likert's scale ranging from "strongly disagree" with a score of 1 to "strongly agree" with a value of 10 . The data gathered for this research were thoroughly screened to avoid any events of missing data and outliers as well as to ensure that everything is normal for valid testing. Subsequently, the path analysis of Structural Equation Modelling (SEM) was used for data analysis in terms of weights of constructs and the model fit. Findings of the analysis were then used to resolve the five hypotheses that have been outlined earlier.

\section{Respondents' Profile}

Based on the data presented in Table 1, the majority of the respondents ( 81 per cent) were between the ages of 21 to 40 years old. The respondents were mostly Malays, all of the 140 women academicians in this study were Muslims, and 88 per cent have obtained a master's degree. Furthermore, 70 per cent of these academicians were lecturers, 24 per cent were senior lecturers, four per cent were associate professors, and the rest were nonpermanent lecturers. In terms of working experience, 78 per cent of the respondents have worked less than and equal to ten years. As such, they are considered as young lecturers whose primary focus is on teaching. Forty-four per cent of them had a total workload of 13 to 17 hours per week, and 30 per cent of the respondents had 18 to 22 hours of workload per week. Nevertheless, 75 per cent of them were not in charge of the administrative division at the university.

Also, 66 per cent of the respondents were married, and a large proportion of these lecturers' spouse (87 per cent) was employed. Only 35 per cent of them did not have any children, and the rest had one or more than one child. Since the household chores would increase for those who have children, most spouses would continually offer help around the 
house (60 per cent). Concerning the data in this study, the household chores would be even more challenging by 48 per cent for respondents who had children of less than six years of age and had not attended school. Fifty-two per cent of the respondents had at least one child at school, while the most significant proportion comprising of 38 per cent of the respondents used the daycare service centre to send their children.

Table 1: Respondents' Profile

\begin{tabular}{|c|c|c|c|c|c|}
\hline Items & Total & Percentage & Items & Total & Percentage \\
\hline \multicolumn{3}{|l|}{ Gender } & \multicolumn{3}{|l|}{ Number of children } \\
\hline \multirow[t]{2}{*}{ Female } & 140 & 100 & No & 14 & 15 \\
\hline & & & 1 & 24 & 26 \\
\hline Age & & & 2 & 16 & 17 \\
\hline $21-30$ & 50 & 36 & 3 & 19 & 20 \\
\hline $31-40$ & 63 & 45 & 4 & 11 & 12 \\
\hline $41-50$ & 21 & 15 & 5 & 5 & 5 \\
\hline $51-60$ & 6 & 4 & More than 5 & 4 & 4 \\
\hline \multicolumn{3}{|l|}{ Race } & \multicolumn{3}{|l|}{ Number of children in school } \\
\hline Malay & 138 & 99 & 0 & 45 & 45 \\
\hline Others & 2 & 1 & 1 & 12 & 13 \\
\hline \multicolumn{3}{|l|}{ Religion } & 2 & 10 & 11 \\
\hline Islam & 140 & 100 & 3 & 12 & 13 \\
\hline \multicolumn{3}{|l|}{ Educational Level } & 4 & 8 & 9 \\
\hline Bachelor's Degree & 4 & 3 & 5 & 3 & 3 \\
\hline Master's Degree & 123 & 88 & More than 5 & 3 & 3 \\
\hline PhD & 13 & 9 & \multicolumn{3}{|c|}{ Who is taking care of the children } \\
\hline \multicolumn{3}{|l|}{ Rank } & Spouse & 20 & 25 \\
\hline Assoc. Professor & 6 & 4 & Parents & 10 & 13 \\
\hline Senior Lecturer & 34 & 24 & Parents in law & 2 & 3 \\
\hline Lecturer & 96 & 70 & Maid / servant & 8 & 10 \\
\hline Others & 3 & 2 & Day Care Centre & 37 & 38 \\
\hline \multicolumn{3}{|l|}{ Seniority } & Others & 1 & 1 \\
\hline$<6$ years & 65 & 47 & \multicolumn{3}{|c|}{ Number of hours per day spent with the children } \\
\hline 6 to 10 years & 43 & 31 & 2 to 3 hours & 6 & 6 \\
\hline 11 to 20 years & 27 & 19 & 3 to 4 hours & 11 & 12 \\
\hline 21 to 30 years & 3 & 2 & 4 to 5 hours & 28 & 30 \\
\hline$>30$ years & 2 & 1 & More than 5 hours & 33 & 36 \\
\hline \multicolumn{3}{|l|}{ Workload } & Not applicable & 15 & 16 \\
\hline$<8$ hours & 9 & 7 & \multicolumn{3}{|l|}{ Other responsibilities } \\
\hline 8 to 12 hours & 18 & 13 & Older people & 27 & 19 \\
\hline 13 to 17 hours & 61 & 44 & Dependent adult & 5 & 4 \\
\hline 18 to 22 hours & 41 & 30 & Adult with disabilities & 4 & 3 \\
\hline More than 22 hours & 5 & 6 & Children with disabilities & 5 & 4 \\
\hline \multicolumn{3}{|l|}{ Administration position } & Others & 21 & 15 \\
\hline Yes & 35 & 25 & \multicolumn{3}{|l|}{ Maid } \\
\hline No & 103 & 75 & Yes & 5 & 4 \\
\hline \multicolumn{3}{|l|}{ Marital Status } & No & 135 & 96 \\
\hline Single & 47 & 34 & \multicolumn{3}{|c|}{ Spouse help household chores } \\
\hline Married & 93 & 66 & Never & 4 & 4 \\
\hline \multicolumn{3}{|l|}{ Spouse employed } & Rarely & 5 & 5 \\
\hline Yes & 81 & 87 & Sometimes & 28 & 30 \\
\hline \multirow[t]{2}{*}{ No } & 9 & 10 & Often & 16 & 17 \\
\hline & & & Always & 40 & 43 \\
\hline
\end{tabular}

Table 1 also shows that there is approximately 36 per cent of respondents who spent more than 5 hours per day with their children and 16 per cent had no time to spend with their children due to the long hours of commute. They were forced to have a long daily commute 
as they want to live with their spouses and therefore needed to live far from their workplace. Due to the stress resulting from this routine, they would be more likely to experience family or work conflict. Besides that, some of our respondents also had other responsibilities such as caring for elderly or parents (19 per cent), dependent adult (4 per cent), an adult with disabilities ( 3 per cent), children with disabilities (4 per cent), and others ( 15 per cent). It is important to note that most respondents ( 96 per cent) did not employ any maid or helper to help them manage their household chores and family as they were not financially capable. Most of the sampled respondents received help from spouse, parents, and parents in law in taking care of their children.

\section{Confirmation Factor Analysis}

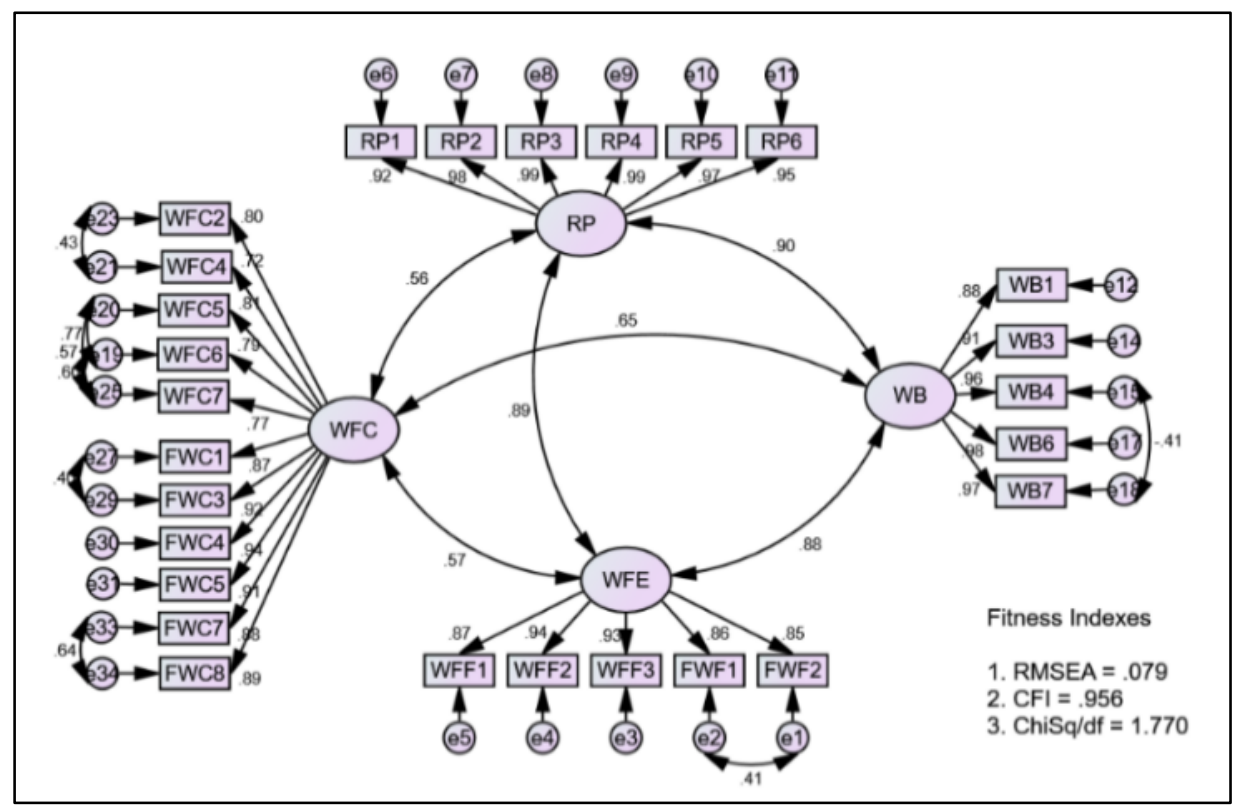

Figure 2: The CFA Results

Note. WFC = work-family conflict; WFE = work-family enrichment; RP = Religious Practice; WB $=$ Well-being

Figure 2 represents fitness indexes, factor loading and the correlation between constructs. The items for each construct (WFC, WFE, RP and WB) are greater than 0.6, which shows that all the corresponding items for each construct are all critical. The correlation value between the construct is at least 0.56 , and the highest correlation value $(0.90)$ is between RP and WB. It indicates a strong positive correlation between these constructs. Overall, the confirmatory factor analysis (CFA) results indicate the fitness indices of absolute fit, incremental fit, and parsimonious fit have all achieved the required level (Awang et al., 2018), with $\mathrm{RMSEA}=0.079, \mathrm{CFI}=0.956$ and $\mathrm{ChiSq} / \mathrm{df}=1.770$. These figures were all in acceptable ranges, as suggested by the literature. Therefore, uni-dimensionality was achieved, and our model has successfully yielded a suitable fit. 


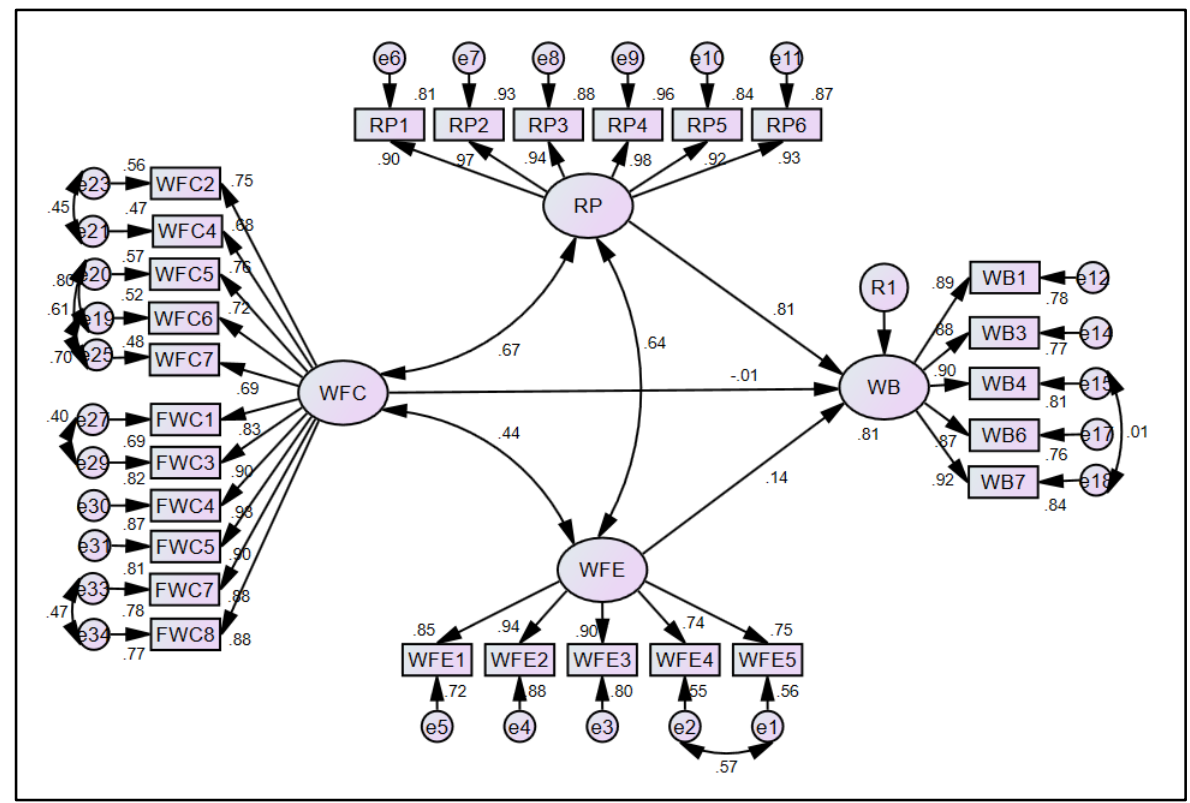

\section{Structural Equation Modelling}

Figure 3: The Standardised Path Coefficients (Direct Relationship)

Note. WFC = work-family conflict; WFE = work-family enrichment; RP = Religious Practice; WB $=$ Well-being

Table 2: The Regression Path Coefficient and its Significance

\begin{tabular}{lllll}
\hline Relationships & Estimate & SE. & CR. & Results \\
\hline Work-Family Conflict $\rightarrow$ Well-Being & -.010 & .079 & -.124 & Not supported \\
Work-Family Enrichment $\rightarrow$ Well-Being & $.134^{*}$ & .058 & 2.326 & Supported \\
Religiosity $\rightarrow$ Well-Being & $.780^{* * *}$ & .082 & 9.566 & Supported \\
\hline
\end{tabular}

Notes: $\mathrm{N}=140 ;{ }^{*}$ Significant at the $\mathrm{p}<0.05,{ }^{* * *}$ Significant at the $\mathrm{p}<0.001$

The regression path coefficients of the direct relationship between constructs are illustrated in Figure 3 and Table 2 above. Figure 3 discovers the coefficient value of determination $R^{2}$ value of 0.81 . The figure indicates work-family conflict, work-family enrichment, and religiosity contribute a significant relationship to well-being which is 81 per cent. Results from Table 2 explicitly imply that the influence of work-family conflict on wellbeing was not significant $(\beta=-.010, p>.05)$. The result contradicts our expectation that workfamily conflict may negatively affect well-being. Therefore, the first hypothesis $(\mathrm{H} 1)$ is rejected. Furthermore, the influence of work-family enrichment was significant positive for well-being ( $\beta=0.134 p<.001$ ). The findings also depict that the influence of religiosity on wellbeing was significant $(\beta=0.780, p<.001)$. Hence, only two hypotheses are supported $(\mathrm{H} 2$ and $\mathrm{H} 3$ ), and between these two factors, religiosity displays a more significant contribution to well-being compared to work-family enrichment. 


\section{Testing the Mediation Effects}

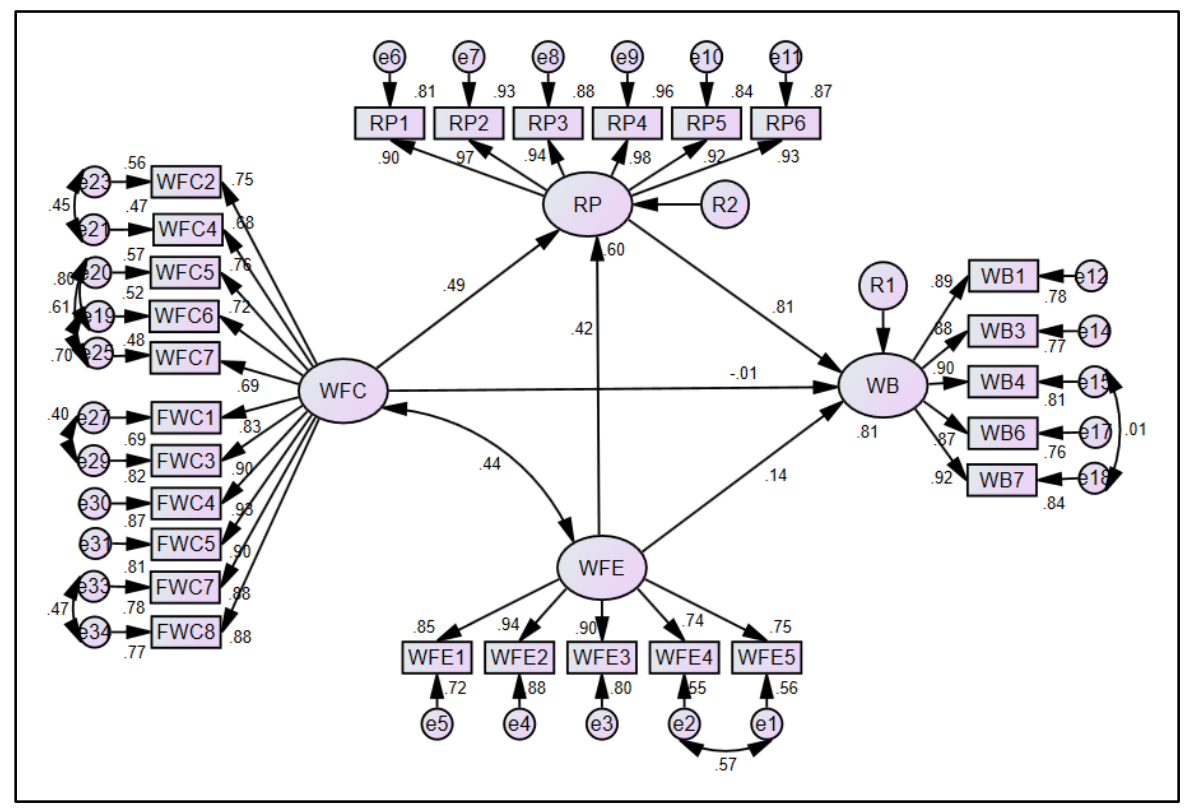

Figure 4: The Standardised Path Coefficients between Constructs

Note. $\mathrm{WFC}=$ work-family conflict; $\mathrm{WFE}=$ work-family enrichment; RP = religious Practice; $\mathrm{WB}$ = well-being

Table 3: Testing Religiosity as a Mediator in the Relationship between Work-Family Conflict and Well-Being (The Regression Path Coefficient)

\begin{tabular}{|l|l|l|l|l|}
\hline Relationships & Estimate & SE. & CR. & Results \\
\hline $\begin{array}{l}\text { (a) Work-Family Conflict } \rightarrow \\
\text { Religiosity }\end{array}$ & $.661^{* * *}$ & .106 & 6.243 & Significant \\
\hline $\begin{array}{l}\text { (b) Religiosity } \rightarrow \text { Well-Being } \\
\text { (c) Work-Family Conflict } \rightarrow \text { Well- } \\
\text { Being }\end{array}$ & $.780^{* * *}$ & .082 & 9.566 & Significant \\
\hline (a) $\times(b)$ & .516 & .079 & .124 & Not Significant \\
\hline (a) $x(b)>$ (c) & $\begin{array}{l}\text { Mediation } \\
\text { Occurs }\end{array}$ & $\begin{array}{l}\text { Full Mediation since the direct } \\
\text { effect is not significant }\end{array}$ \\
\hline
\end{tabular}

Notes: $\mathrm{N}=140 ; * * *$ Significant at the $\mathrm{p}<0.001$

Concerning the direct relationship between work-family conflict and religiosity, results reveal that religiosity mediated the relationship between work-family conflict and well-being (see Table 3). The mediating effect denotes that work-family conflict was associated with wellbeing through religiosity. Also, it can be deduced that religiosity had full mediation effects as the direct effect of work-family conflict on well-being was not significant after the mediator entered the model. Therefore, the fourth hypothesis $(\mathrm{H} 4)$ is supported. 
Table 4: Testing Religiosity as a Mediator in the Relationship between Work-Family Enrichment and Well-Being (The Regression Path Coefficient)

\begin{tabular}{|l|l|l|l|l|}
\hline & Estimate & SE. & CR. & Results \\
\hline $\begin{array}{l}\text { (a) Work-Family Enrichment } \rightarrow \\
\text { Religiosity }\end{array}$ & $.422^{* * *}$ & .075 & 5.682 & Significant \\
\hline $\begin{array}{l}\text { (b) Religiosity } \rightarrow \text { Well-Being } \\
\begin{array}{l}\text { (c) Work-Family Enrichment } \rightarrow \text { Well- } \\
\text { Being }\end{array}\end{array}$ & $.780^{* * *}$ & .082 & 9.566 & Significant \\
\hline (a) $x($ b) & .329 & .058 & 2.326 & Significant \\
\hline (a) $x(b)>$ (c) & $\begin{array}{l}\text { Mediation } \\
\text { Occurs }\end{array}$ & $\begin{array}{l}\text { Partial Mediation since the } \\
\text { direct effect is not significant }\end{array}$ \\
\hline
\end{tabular}

Notes: $\mathrm{N}=140 ;{ }^{*}$ Significant at the $\mathrm{p}<0.05,{ }^{* * *}$ Significant at the $\mathrm{p}<0.001$

Nonetheless, the analysis of mediation effect as portrayed in Table 4 suggests that religiosity mediated the relationship between work-family enrichment and well-being. The mediating effect denotes that work-family enrichment was associated with well-being through religiosity, while work-family enrichment had both direct and indirect effects on wellbeing. Also, it can be deduced that religiosity had partial mediation effects as the direct effect of work-family enrichment on well-being was still significant after the mediator entered the model. Therefore, the fifth hypothesis (H5) is supported.

\section{Discussion}

The current research aims to determine the relationships between work-family conflict, work-family enrichment, religiosity and well-being. As noted earlier, we expect that religiosity is the salient coping strategy that may function as a mediator in the relationship between work-family conflict, work-family enrichment, and well-being. Therefore, the other research aims are to identify the indirect relationship between those constructs with religiosity acting as a mediator. Although the sample size does not allow generalisation, some of the findings are essential.

Our results based on the responses of 140 Muslim women academicians provide empirical evidence that there is a significant and positive relationship between religiosity and well-being. This result is predictable based on the high mean score on religiosity among Muslim women academicians. The descriptive analysis indicates that 73.6 per cent of our respondents consider themselves as religious. The result implies that religiosity is the most important guidance to all Muslims in achieving well-being in life. Thus, religiosity may be the best predictor to well-being, as shown in Table 4, which contributes the highest $\beta$ estimate ( $\beta$ =.780). This finding is congruent with the research of Noor (2008), Mollidor, Hancock, and Pepper (2015), Nell and Rothmann (2018). In further support, the present result is compatible with previous findings observed in Muslims in other countries like Kuwait (Abdel-Khalek, 2012; 2019), and Indonesia (Pramesona \& Taneepanichskul, 2018). Moreover, many results of studies carried out on other religions, i.e., Christian, have reached the same conclusion. According to Krause et al. (2011), Christians build their social networks and support systems by attending church in which a sense of belonging is consequently established for better physical and mental health. In addition, a study conducted by Doane (2013) on Christian 
undergraduate students also found that religious service attendance has a positive and significant effect on life satisfaction.

The current study discovers that there is an insignificant influence of work-family conflict on well-being. This result contradicts previous researchers' conclusion regarding the relationship between work-family conflict and well-being. Generally, majority of the findings obtained in the prior studies (Aziz et al., 2018; Gözü et al., 2015; Koyuncu et al., 2012; Noor, 2010; Qiao et al., 2011) report a negative relationship between work-family conflict and wellbeing. Nevertheless, such results were not entirely conclusive. Zhang, Griffeth and Fried (2012) gain the same result as our study in which they did not find any correlation between work-family conflict and life satisfaction of Chinese managers. Similarly, other studies also find an insignificant relationship between work-family conflict and job satisfaction (Ng et al., 2016), and between work-family conflict and life satisfaction (Aryee et al., 1999). Interestingly, Choi and Kim (2012) argue that conflict between work and family domains was revealed to have a positive effect on job satisfaction. Notwithstanding, the failure of the present study to verify the negative relationship between work-family conflict and well-being is a significant contribution to the existing knowledge.

A potential reason for the conflicting findings between the current study and the prior scholars (Gözü et al., 2015; Koyuncu et al., 2012; Noor, 2010; Qiao et al., 2011) could be due to our respondents' characteristics. Our respondents may feel continually assisted by their spouse (60 per cent of respondents) in managing domestic responsibilities (Table 1), a shared responsibility that does not negatively impact women's well-being. It is also possible that the demands of work and families faced by these Muslim women academicians are still manageable and within their control, and therefore it does not directly affect their well-being. Some researchers (Aryee et al., 1999) suggest that individuals with an internal locus of control believe their ability to control the situation and influence the outcomes. Therefore, they would be more likely to work harder and smarter in completing work and family demands, which could result in better utilisation of resources in both domains.

Although UiTM lecturers have more teaching hours than lecturers in other Malaysian public universities, it should be noted that the profession as an academician also has the advantage of flexible working time. Thus, the insignificant relationship between work-family conflict and well-being could be the result of the flexible working time enjoyed by this particular sample. The other possible explanation is that there may be some unique antecedents exist for work-family conflict. Prior researchers argue that work-family conflict is not on a continuum, but preferably two distinct constructs that may be influenced by different personality traits (Frone et al., 1992). Hence, it is possible that when work interferes with family, an individual views it as an opportunity, rather than a threat (Yang et al., 2000). If this happens, then work-family conflict will not negatively affect well-being. Hence, these arguments could possibly explain why these Muslim women academicians' well-being is not negatively influenced by the work-family conflict. This argument, however, warrants further investigations.

As an extension of the work-family conflict study, we explore the role of religiosity to mediate the relationship between work-family conflict and well-being. Our study provides evidence to support the idea that religiosity is a vital construct in order to understand the 
determining factors that may influence well-being among Muslim women academicians. The structural equation modelling analysis shows that religiosity significantly mediated the relationship between work-family conflict and well-being. In other words, the high levels of conflict between work and family domains will be associated with higher religiosity, which in turn will be related to high well-being. This result indicates that Muslim women academicians who face stress, fatigue, strain, and anxiety to meet work and family demands, make them more religious and seek God's help as a coping strategy to resolve their conflicts, making them an ideal source of well-being. As a Muslim, we believe that all challenges come from God, whether happy or unhappy. That is the sign that God loves us. How we accept and meet these challenges will make us mature and better in life either in this world or in the hereafter. Muslims believe that God is always with us and that whatever comes and goes can be met with patience, calmness, and prayer. God says;

"Indeed, there is the ease with hardship. Most certainly, there is the ease with hardship."

(Quran 94: 5-6)

This verse has been repeated twice to assure the believers that Allah has promised that after some hardship, there will be ease. So, no matter how challenging a conflict, we fully trust His assurance that everything will be fine. God also says;

"Soon, you shall remember what I say to you. I entrust my affairs to Allah. Surely Allah is watchful over His servants" (Quran 40:44).

This verse shows the importance of putting our faith and utmost trust to Him that He knows best. So as Muslims, we have been taught through the Quran to seek His guidance in whatever situation we are in - good or bad, and then we leave it to Him - the best disposer of all. This eases the life pain, and this assures calmness of mind and soul, thus better well-being of a Muslim. A hadith narrated by Abu Sa'id Al-Khudri and Abu Huraira, the Prophet Muhammad

"No fatigue, nor disease, nor sorrow, nor sadness, nor hurt, nor distress befalls a Muslim, even if it were the prick he receives from a thorn, but that Allah expiates some of his sins for that." (Sahih al-Bukhari 5641 \& 5642).

Based on the above hadith, Muslims believe that every test that was inflicted on them will be rewarded with forgiveness by God. The conflict between work and family for Muslim women academicians is also considered as a test, and as Muslims, we believe patience in dealing with this test will be rewarded with forgiveness of sins. This religious belief could contribute to the well-being of Muslim women academicians.

The descriptive analysis identifies that 62 respondents had additional responsibilities, in which they were also taking care of older parents, dependent adults, adults with disabilities, children with disabilities, and others. It was initially expected that these additional responsibilities would increase the family-work conflict, thus, leading Muslim women academicians to get closer to the Creator in search of help and serenity, which ultimately leads to well-being. This is in line with the teachings of Islam that advocate humans need to 
grow closer to God when faced with tests in life in order to achieve well-being. Hence, our finding provides some initial support for the notion that anyone who sincerely cares for older parents and the disabled solely with an expectation to be rewarded by God, they will be delighted with these additional responsibilities without feeling burdened. Hence, this sincere expectation can also explain the increase in their well-being.

This result is consistent with the previous findings by Hassan et al. (2010), in which their results revealed that three-quarters of their respondents looked after their elderly parents, and 72 per cent of respondents considered themselves as religious. They also found that the responsibility of taking care of older adults collectively contributed to the familywork conflict. Notwithstanding, most religions encourage children to care for elderly parents. Islamic teachings emphasise children's obligation to care for their elderly parents as mentioned in the Quran;

"Your Lord has decreed: (i) Do not worship any but Him; (ii) Be good to your parents; and should both or any one of them attain old age with you, do not say to them even "fie" neither chide them, but speak to them with respect, and be humble and tender to them and say: "Lord, show mercy to them as they nurtured me when I was small". (Quran 17: 23-24)

It appears that, in some cases, the responsibility of caring for the elderly which is said to contribute to the family-work conflict is regarded as a source of blessing to the child's life and enables them to achieve well-being. This statement may support the argument of how workfamily conflict can increase religiosity that would subsequently improve well-being for Muslim women academicians.

Concerning work-family enrichment and well-being, consistent with our expectation, Muslim women academicians who perceived more significant work-family enrichment would report higher well-being. As hypothesised, the finding that enrichment between work and family roles enhances women well-being corroborates that of Culbertson et al. (2012). It means that experience or participation in one-role increases the quality in the other role has improved the well-being of Muslim women academicians. Zhang et al. (2012) claim that work could enhance individual and family benefits in terms of financial, and it is essential in maintaining the living standard, thus can improve well-being. Moreover, academicians can often enjoy the enhancement of knowledge through various workshops and seminars organized by the university. The enrichment of knowledge gained in this workplace is able to increase self-esteem, enhance skills, creativity and innovation (Fakhrorazi et al., 2019). In addition, the academicians also have the opportunities to contribute to society in the form of dissemination of knowledge and skills as well as the organization of voluntary programs to help local communities. The enrichment of this work domain is expected to delight Muslim women academicians and make their functional roles at home as wives and mothers become more efficient, which in turn improves their well-being.

The structural equation modelling analysis also shows that religiosity played a mediator role in the relationship between work-family enrichment and well-being. This study has primarily discovered that work-family enrichment will lead to religious practice and that it eventually will have a positive impact on well-being. This empirical evidence shows that the 
inclusion of religiosity into the model will reduce the association between work-family enrichment and well-being. Note that the indirect effect of work-family enrichment and wellbeing via religiosity $(\beta=0.329)$ was higher than the direct effect of work-family enrichment and well-being $(\beta=0.134)$. Hence, instead of the role as a direct antecedent to well-being, work-family enrichment had an indirect influence on well-being through religiosity as well, which demonstrated as a mediator effect. The research findings in this study have thus provided further empirical evidence to support and validate the role of religiosity as a mediator in the relationship between work-family enrichment and well-being, which is not discovered in previous research.

To put these findings in the right interpretational context, it is crucial to highlight that the Muslim women academicians who participated in this study were well-educated and highincome earners (Fakhrorazi et al., 2019). Therefore, it is highly likely that among Muslim women academicians (who cannot be regarded as representing the entire academicians in all universities), who are often perceived by the society as having high occupational status and a strong financial position, gratitude may be firmly inculcated to cause the respondents to practise their religion. It means, the more a Muslim woman academician perceived benefits of her work and her family, the more she is grateful and brings herself closer to The Almighty. This ultimately may affect positive well-being among Muslim women academicians.

Islam teaches that every enjoyment and success is not solely due to one's hard work, but it is happening by the permission and will of The Creator. Given that all respondents are Muslims, an explanation of how Islam teaches its adherents to work hard and be patient in conflict may be a reasonable explanation for this finding. Work is the responsibility of Muslim, and it is a way to get the blessing of Allah. In Islam, work is considered a good deed and responsibility entrusted to humankind by God. Allah will reward Muslims in this world and hereafter for their excellent works in providing food and sustenance for their families and the needy. By having good work and income, a Muslim can support his family and other Muslims as well as contributing to the development of Islam. Islam also considers work as a way to get forgiveness from Allah; anybody who does excellent work and work hard in accordance with Syariah will get forgiveness from Allah. As narrated by Aisyah, the Prophet Muhammad says:

"Anybody work hard will be forgiven by Allah". (Hadith narrated by Tabrani and Bukhari)

In addition, Ibnu Abbas R.A says, I heard The Prophet of Muhammad says:

"Anybody feels tired in the evening because of his work; hence, his sins will be forgiven by Allah that evening." (Hadith narrated by Imam Tabrani in Al-Mu'jam Al-Ausath VII/289)

"That Allah to love Muslims who work hard in searching for their sustenance". (Hadith narrated by Tabrani and Bukhari)

Hence, these hadiths also support the finding of this study, in which work-family enrichment will lead Muslim women academicians to practice their religion and ultimately improve their 
well-being. In other words, the more they enjoy their work and family enrichment, the more they are grateful and refine their religious duties, which will ultimately make them happier.

\section{Conclusions}

This study has implications for Muslim women academicians by clarifying the impacts of work-family conflict, work-family enrichment, and religiosity as the contributors of wellbeing. This study suggests that to improve well-being, Muslim women academicians have to start by increasing obedience to God by practising all the Islamic teachings, such as performing prayers, fasting, paying alms, reciting the Holy Quran, practising zikr (remembrance of God), and making supplications. Since this study reiterates the findings gathered from Christian participants which see a significant impact of religiosity on well-being (Krause et al., 2011; Doane, 2013), people should be encouraged to do all the good deeds as taught by their respective religions to achieve well-being.

We also examine the mediating effect of religiosity in the work-family conflict-wellbeing relationship and work-family enrichment-well-being relationship. The findings of this study confirm that work-family conflict and work-family enrichment have indirect impacts on well-being through improved religiosity. According to these findings, conflicting and enriching aspects of work and family will help Muslim women academicians to increase their religiosity and in turn, improve their well-being. These results also imply that no matter how much conflict faced between work and family domains, or no matter how enriching both domains are, it cannot assure Muslim women academicians' well-being if they do not improve their religiosity. This makes sense as well-being could be achieved when Muslim women academicians are able to manage the conflict between work and family demands and enjoy the benefits of both domains through the adherence of religious teachings. This means that when Muslim women academicians face a conflict between work and family, they need to improve their religion and seek Allah's guidance to resolve the conflict in order to achieve well-being. Similarly, if they enjoy the benefits of both work and family domains, then they still need to refine their religious duties as a sign of gratitude and that God may increase their well-being.

In order to retain talented Muslim women academicians, the university needs to understand that the major obstacle to the careers development of Muslim women academicians is the time constraints and lack of energy to fulfil their multiple social roles as wives, mothers and employee (Achour et al., 2014; Fakhrorazi et al., 2019; Gewinner, 2019). In that regard, the university can host various seminars and workshops to prepare Muslim women academicians to take on their challenging tasks in a professional manner to keep their talents continually acknowledged. Among the programs that can be organised include skillsbased programs such as time management skills, assertiveness skills, decision-making skills, and technological skills.

In sum, the present study was designed to explore the mediating role of religiosity in the relationships between work-family conflict, work-family enrichment, and well-being. Findings of this research can contribute to the body of literature that examines the issue of work-family conflict, work-family enrichment and well-being, as well as enhancing the comprehension of the role of religiosity in this context. Through structural equation modelling, this study has successfully analysed the mediating role of religiosity in relation to 
work-family conflict, work-family enrichment and well-being. This mediator provides a possible mechanism to understand how to lower work-family conflict among women academicians, and hopefully, through further research, it will benefit all employees.

In the nutshell, the main implication of this research for Muslim women academicians is that they should implement strategies to overcome work-family conflict through religious concepts. This empirical study has expanded the literature on well-being by showing that religiosity may shield women academicians against the negative effects of work-family conflict. In addition, the nature of gratitude in the concept of religiosity is also seen to increase the influence of work-family enrichment on the well-being of Muslim women academicians.

Nonetheless, it was discovered that work-family conflict has an insignificant impact on well-being. Thus, the following step should be employed to evaluate factors that cause the insignificant effects between work-family conflict and well-being among Muslim women academicians. Furthermore, employing religiosity as a moderator that may strengthen the relationship between work-family conflict and well-being is also a productive subject for further research, and the present study has provided the foundation for future exploration.

The limitation of this study is our lack of data, in which this study only uses a sample of 140 Muslim women academicians from Universiti Teknologi MARA Pahang. Therefore, the results of this study cannot be generalised to all Muslim women academicians in Malaysia, whose demographic backgrounds and institutional demands could differ significantly from those sampled. For instance, the average teaching workload at University Teknologi MARA is 17 hours per week, compared to other universities that have weekly teaching workload of fewer than 10 hours. As each university varies in terms of job descriptions and job stress, the design of this study may not be applicable for other samples, and differences in the outcome should be expected. Therefore, further studies must be carried out in other universities to validate the role of religiosity as a mediator in the relationships between work-family conflict, work-family enrichment, and well-being. Besides, with its limitation to only a group of Muslim women academicians, it may thus reduce the applicability of the current findings to female samples in other industries. Due to these limitations, the findings should be interpreted with caution in supporting the findings of future studies.

With regards to gender, women are considered to have a strong emotional attachment to the responsibility of managing the household chores and caring for children as compared to men. Therefore, gender differences may influence how men and women resolve conflicts between work and family demands. Furthermore, some researchers said that there is a possibility of gender differences in the level of religiosity in which women reported to have higher religiosity than men (Appel, Park, Wortmann, \& van Schie, 2020). Thus, this study can be replicated in whole or in part, by using male samples to see how gender differences and religiosity level can influence well-being.

\section{References}

Aazami, S., Akmal, S., \& Shamsuddin, K. (2015). A model of work-family conflict and well-being among Malaysian working women. Work, 52(3), 687-695. https://doi.org/10.3233/WOR-152150

Abdel-Khalek, A. M. (2012). Subjective well-being and religiosity: A cross-sectional study with 
adolescents, young and middle-aged adults. Mental Health, Religion \& Culture, 15(1), 39-52.

Abdel-Khalek, A. M. (2019). Religiosity and subjective well-being in the Arab context: addendum and extrapolation. Mental Health, Religion and Culture, 22(8), 860-869. https://doi.org/10.1080/13674676.2019.1687135

Achour, M., Grine, F., Nor, M. R., \& Yusoff, M. Y. Z. (2015). Measuring Religiosity and Its Effects on Personal Well-Being: A Case Study of Muslim Female Academicians in Malaysia. Journal of Religion and Health, 54(3), 984-997. https://doi.org/10.1007/s10943-014-9852-0

Achour, M., Grine, F., \& Roslan, M. N. M. (2014). Work-family conflict and coping strategies: Qualitative study of Muslim female academicians in Malaysia. Mental Health, Religion and Culture, 17(10), 1002-1014. https://doi.org/10.1080/13674676.2014.994201

Achour, M., Nor, M. R., Amel, B., Bin Seman, H. M., \& Yusoff, M. Y. Z. (2017). Religious Commitment and its Relation to Happiness among Muslim Students: The Educational Level as Moderator. Journal of Religion and Health, 56(5), 1870-1889. https://doi.org/10.1007/s10943-017-0361-9

Achour, M., Nor, M. R., \& Yusoff, M. Y. Z. (2015). Work-Family Demands and Subjective Wellbeing among Female Academicians: The Role of Muslim Religiosity. Review of Religious Research, 57(3), 419-433. https://doi.org/10.1007/s13644-015-0221-6

Achour, M., Nor, M. R., \& Yusoff, M. Y. Z. (2016). Islamic Personal Religiosity as a Moderator of Job Strain and Employee's Well-Being: The Case of Malaysian Academic and Administrative Staff. Journal of Religion and Health, 55(4), 1300-1311. https://doi.org/10.1007/s10943-015-0050-5

Ahmad, A. (1996). Work-family conflict among married professional women in Malaysia. The Journal of Social Psychology, 136(5), 663-665. https://doi.org/10.1080/00224545.1996.9714054

Allis, P., \& O'Driscoll, M. (2008). Positive effects of nonwork-to-work facilitation on well-being in work, family and personal domains. Journal of Managerial Psychology, 23(3), 273291. https://doi.org/10.1108/02683940810861383

Appel, J. E., Park, C. L., Wortmann, J. H., \& van Schie, H. T. (2020). Meaning Violations, Religious/Spiritual Struggles, and Meaning in Life in the Face of Stressful Life Events. International Journal for the Psychology of Religion, 30(1), 1-17.

https://doi.org/10.1080/10508619.2019.1611127

Aryee, S., Luk, V., Leung, A., \& Lo, S. (1999). Role stressors, work-family conflict and wellbeing: An examination of the effects of spouse support and coping behaviours among employed parents in Hong Kong. Journal of Vocational Behavior, 54, 259-278. https://doi.org/http://dx.doi.org/10.1006/jvbe.1998.1667

Awang, Z., Hui, L. S., \& Zainudin, N. F. S. (2018). Pendekatan Mudah SEM. MPWS Rich's Publication, Bandar Baru Bangi.

Aziz, N. N. A., Yazid, Z. N. A., Tarmuji, N. H., \& Samsudin, M. A. (2016). The fourfold taxonomy of work-family balance and well-being: The moderating effect of coping strategies. $E$ Academia Journal, 5(1), 1-4. https://doi.org/10.15713/ins.mmj.3

Aziz, N. N. A., Yazid, Z. N. A., Tarmuji, N. H., Samsudin, M. A., \& Majid, A. A. (2018). The Influence of Work-Family Conflict and Family-Work Conflict on Well-Being: The Mediating Role of Coping Strategies. International Journal of Academic Research in Business and Social Sciences, 8(4), 259-275. https://doi.org/10.6007/IJARBSS/v8$\mathrm{i} 4 / 4012$ 
Barbic, A., Stinglhamber, F., Bertrand, F., \& Hansez, I. (2017). Work-Home Interface and WellBeing A Cross-Lagged Analysis. Journal of Personnel Psychology, 16(1), 46-55. https://doi.org/10.1027/1866-5888/a000172

Bromer, J., \& Henly, J. R. (2009). The work-family support roles of child care providers across settings. Early Childhood Research Quarterly, 24(3), 271-288. https://doi.org/10.1016/j.ecresq.2009.04.002

Carlson, D. S., Hunter, E. M., Ferguson, M., \& Whitten, D. (2014). Work-Family Enrichment and Satisfaction: Mediating Processes and Relative Impact of Originating and Receiving Domains. Journal of Management, 40(3), 845-865.

https://doi.org/10.1177/0149206311414429

Carver, C. S., Scheier, M. F., \& Weintraub, J. K. (1989). Assessing coping strategies: A theoretically based approach. Journal of Personality and Social Psychology, 56(2), 267283. https://doi.org/10.1037/0022-3514.56.2.267

Choi, H. J., \& Kim, Y. T. (2012). Work-family conflict, work-family facilitation, and job outcomes in the Korean hotel industry. International Journal of Contemporary Hospitality Management, 24(7), 1011-1028. https://doi.org/10.1108/09596111211258892

Cohen, J. (1988). Statistical power analysis for the behavioural sciences (2nd ed). Hillsdale, NJ: Erlbaum.

Culbertson, S. S., Mills, M. J., \& Fullagar, C. J. (2012). Work engagement and work-family facilitation: Making homes happier through positive affective spillover. Human Relations, 65(9), 1155-1177. https://doi.org/10.1177/0018726712440295

Department of Statistics Malaysia. (2020). Principal Statistics of Labour Force, Malaysia, First Quarter (Q1) 2020.

https://www.dosm.gov.my/v1/index.php?r=column/cthemeByCat\&cat=149\&bul_id=d1 k5WU1GV3kzeUdJS0E4N210VGZSUT09\&menu_id=U3VPMIdoYUxzVzFaYmNkWXZteGd uZz09

Doane, M. J. (2013). The association between religiosity and subjective well-being: The unique contribution of religious service attendance and the mediating role of perceived religious social support. Irish Journal of Psychology, 34(1), 49-66.

https://doi.org/10.1080/03033910.2013.775071

Fakhrorazi, A., Hartini, H., \& Islam, R. (2019). The outcomes of individual absorptive capacity among academicians in Malaysian public universities. Humanities and Social Sciences Reviews, 7(1), 228-238. https://doi.org/10.18510/hssr.2019.7127

Frone, M. R., Russell, M., \& Cooper, M. L. (1992). Antecedents and outcomes of work-family conflict: Testing a model of the work-family interface. Journal of Applied Psychology, 77(1), 65-78. https://doi.org/10.1037//0021-9010.77.1.65

Fung, N. S., Ahmad, A., \& Omar, Z. (2014). Role of work-family enrichment in improving job satisfaction. American Journal of Applied, 11(1), 96-104. https://doi.org/10.3844/ajassp.2014.96.104

Gewinner, I. (2019). Work-life balance for native and migrant scholars in German academia: meanings and practices. Equality, Diversity and Inclusion. https://doi.org/10.1108/EDI02-2019-0060

Gözü, C., Anandarajan, M., \& Simmers, C. A. (2015). Work-family role integration and personal well-being: The moderating effect of attitudes towards personal web usage. Computers in Human Behavior, 52, 159-167. https://doi.org/10.1016/j.chb.2015.05.017

Greenhaus, J. H., \& Powell, G. N. (2006). When work and family are allies: A theory of workfamily enrichment. In Academy of Management Review (Vol. 31, Issue 1, pp. 77-92). 
https://doi.org/10.5465/AMR.2006.19379625

Grönlund, A., \& Öun, I. (2018). In search of family-friendly careers? Professional strategies, work conditions and gender differences in work-family conflict. Community, Work and Family, 21(1), 87-105. https://doi.org/10.1080/13668803.2017.1375460

Halim, R. A., Aziz, N. N. A., Samsudin, M. A. (2016). Malaysian Female Graduates: Marriage, Motherhood and Labour Force Participation. International Journal of Multidisciplinary Research and Development, 3 (1), 109-114.

Harris, S. J. (2001). Religiosity and Psychological Well-Being among Older Adults: A MetaAnalysis.

Hassan, Z., Dollard, M. F., \& Winefield, A. H. (2010). Work-family conflict in East vs Western countries. Cross-Cultural Management: An International Journal, 17(1), 30-49. https://doi.org/10.1108/13527601011016899

Hofäcker, D., \& König, S. (2013). Flexibility and work-life conflict in times of crisis: A gender perspective. International Journal of Sociology and Social Policy, 33(9-10), 613-635. https://doi.org/10.1108/IJSSP-04-2013-0042

Htut, Y., Shahrul, B. K., \& Poi, P. J. H. (2007). The views of older Malaysians on advanced directive and advanced care planning: A qualitative study. Asia-Pacific Journal of Public Health, 19(3), 58-67. https://doi.org/10.1177/101053950701900310

Imam, S. S., Nurullah, A. S., Makol-Abdul, P. R., Rahman, S. A., \& Noon, H. M. (2009). Spiritual and psychological health of Malaysian youths. Research in the Social Scientific Study of Religion, 20, 85-101. https://doi.org/10.1163/ej.9789004175624.i-334.28

Innstrand, S. T., Langballe, E. M., Espnes, G. A., Falkum, E., \& Aasland, O. G. (2008). Positive and negative work-family interaction and burnout: A longitudinal study of reciprocal relations. Work \& Stress, 22, 1-15. https://doi.org/10.1080/02678370801975842

Jacobs, J. A., \& Winslow, S. E. (1998). Overworked Faculty : Job Stresses and Family Demands The Mommy Track and Partnership : Temporary Delay or Dead End ? 254-255.

Jones, M. S., Teel, T. L., Martinez, D. E., \& Solomon, J. (2020). Conflict and adaptation at the intersection of motherhood and conservation leadership. Biological Conservation, 243(February), 108487. https://doi.org/10.1016/j.biocon.2020.108487

Kaliampos, A., \& Roussi, P. (2017). Religious beliefs, coping, and psychological well-being among Greek cancer patients. Journal of Health Psychology, 22(6), 754-764. https://doi.org/10.1177/1359105315614995

Kallaith, P. (2014). Is work-family enrichment an antidote to experiences of psychological strain among Australian social workers? An empirical study. Australian Social Work, 67, 332-347. https://doi.org/10.1080/0312407X.2013.825302

Karatepe, O. M., \& Magaji, A. B. (2008). Work-Family Conflict and Facilitation in the Hotel Industry: A Study in Nigeria. Cornell Hospitality Quarterly, 49(4), 395-412. https://doi.org/10.1177/1938965508326282

Osman, K. M., \& Bekteshi, L. (2008). Antecedents and outcomes of work-family facilitation and family-work facilitation among frontline hotel employees. International Journal of Hospitality Management, 27(4), 517-528.

https://doi.org/10.1016/j.ijhm.2007.09.004

Koyuncu, M., Burke, R. J., \& Wolpin, J. (2012). Work-family conflict, satisfaction and psychological well-being among women managers and professionals in Turkey. Gender in Management, 27(3), 202-213. https://doi.org/10.1108/17542411211221286

Krause, N., Shaw, B., \& Liang, J. (2011). Social Relationships in Religious Institutions and Healthy Lifestyles. Journal Of Health Education Behavior, 38(1), 25-38. 
https://doi.org/10.1177/1090198110370281

Krok, D., Brudek, P., \& Steuden, S. (2019). When Meaning Matters: Coping Mediates the Relationship of Religiosity and Illness Appraisal with Well-Being in Older Cancer Patients. International Journal for the Psychology of Religion, 29(1), 46-60. https://doi.org/10.1080/10508619.2018.1556061

Lazarus, R. S. (1999). Stress and coping: A new synthesis. Springer.

Leung, Y. K., Mukerjee, J., \& Thurik, R. (2020). The role of family support in work-family balance and subjective well-being of SME owners. Journal of Small Business Management, 58(1), 130-163. https://doi.org/10.1080/00472778.2019.1659675

Matthews, R. A., Bulger, C. A., \& Barnes-Farrell, J. L. (2010). Work social supports, role stressors, and work-family conflict: The moderating effect of age. Journal of Vocational Behavior, 76(1), 78-90. https://doi.org/10.1016/j.jvb.2009.06.011

Mollidor, C., Hancock, N., \& Pepper, M. (2015). Volunteering, religiosity and well-being: interrelationships among Australian churchgoers. Mental Health, Religion and Culture, 18(1), 20-32. https://doi.org/10.1080/13674676.2014.1003169

Momtaz, Y. A., Hamid, T. A., \& Yahaya, N. (2009). The role of religiosity on the relationship between chronic health problems and psychological well-being among Malay Muslim older persons. Research Journal of Medical Sciences, 3(6), 188-193.

Momtaz, Y. A., Hamid, T. A., Yahaya, N., \& Ibrahim, R. (2010). Religiosity among older Muslim Malaysians: A gender perspective. Journal of Muslim Mental Health, 5(2), 210-220. https://doi.org/10.1080/15564908.2010.487731

Momtaz, Y., Ibrahim, R., Hamid, T., \& Yahaya, N. (2010). Mediating effects of social and personal religiosity on the psychological well being of widowed older people. Omega: Journal of Death and Dying, 61(2), 145-162. https://doi.org/10.2190/OM.61.2.d

Nell, W., \& Rothmann, S. (2018). Hope, religiosity, and subjective well-being. Journal of Psychology in Africa, 28(4), 253-260. https://doi.org/10.1080/14330237.2018.1505239

$\mathrm{Ng}$, L., Kuar, L., \& Cheng, W. (2016). Influence of Work-Family Conflict and Work-Family Positive Spillover on Healthcare Professionals ' Job Satisfaction. Business Management Dynamics, 5(11), 1-15.

Noor, N. M. (2008). Work and women's well-being: Religion and age as moderators. Journal of Religion and Health, 47(4), 476-490. https://doi.org/10.1007/s10943-008-9188-8

Noor, N. M. (2010). Work-Family Conflict, Work-and Family-Role Salience, and Women's WellBeing. The Journal of Social Psychology, October 2012, 37-41.

Nwagbara, U. (2020). Institutions and organisational work-life balance (WLB) policies and practices. Journal of Work-Applied Management, 12(1), 42-54.

https://doi.org/10.1108/jwam-11-2019-0035

Park, C. L. (2005). Religion as a meaning-making framework in coping with life stress. Journal of Social Issues, 61(4), 707-729. https://doi.org/10.1111/j.1540-4560.2005.00428.x

Peeters, M., Waltz, C., Demerouti, E., \& de Regt, W. (2009). Work-family culture, work-family interference and well-being at work: Is it possible to distinguish between a positive and a negative process? Career Development International, 14(7), 700-713. https://doi.org/10.1108/13620430911005726

Phipps, S. T. A., \& Prieto, L. C. (2016). A Discovery of Early Labor Organisations and the Women who Advocated Work-Life Balance: An Ethical Perspective. Journal of Business Ethics, 134(2), 249-261. https://doi.org/10.1007/s10551-014-2428-9

Pramesona, B. A., \& Taneepanichskul, S. (2018). The effect of the religious intervention on depressive symptoms and quality of life among Indonesian elderly in nursing homes: A 
quasi-experimental study. Clinical Interventions in Aging, 13, 473-483. https://doi.org/10.2147/CIA.S162946

Qiao, G., Li, S., \& Hu, J. (2011). Stress, coping, and psychological well-being among new graduate nurses in China. Home Health Care Management and Practice, 23(6), 398-403. https://doi.org/10.1177/1084822311405828

Quran 2: 153, Islamicstudies.info,

https://www.islamicstudies.info/tafheem.php?sura=2\&verse $=152 \&$ to $=163$

Quran 13: 28, Islamicstudies.info, https://www.islamicstudies.info/tafheem.php?sura=13\&verse $=27 \&$ to $=31$

Quran 13: 29, Islamicstudies.info, https://www.islamicstudies.info/tafheem.php?sura=13\&verse=27\&to=31

Quran 14: 7, Islamicstudies.info, https://www.islamicstudies.info/tafheem.php?sura=14\&verse $=7 \&$ to $=12$

Quran 17: 23-24,Islamicstudies.info, https://www.islamicstudies.info/tafheem. php?sura=14\&verse $=23 \&$ to $=30$

Quran 27: 40, Islamicstudies.info, https://www.islamicstudies.info/tafheem. $p h p$ ?sura=27\&verse=32\&to=44

Quran 31: 12, Islamicstudies.info, https://www.islamicstudies.info/tafheem.php?sura=31\&verse $=12 \&$ to $=19$

Quran 40: 44, Islamicstudies.info, https://www.islamicstudies.info/tafheem. php?sura $=40 \&$ verse $=38 \&$ to $=50$

Quran 94: 5-6, Islamicstudies.info, https://www.islamicstudies.info/tafheem.php?sura=94\&verse $=1 \&$ to $=8$

Raffenaud, A., Unruh, L., Fottler, M., Liu, A. X., \& Andrews, D. (2020). A comparative analysis of work-family conflict among staff, managerial, and executive nurses. Nursing Outlook, 68(2), 231-241. https://doi.org/10.1016/j.outlook.2019.08.003

Lexshimi, R. G., Fahmi, M. E., Lee, S. C., Suhana, N. H., Norhazirah, H., \& Sh Ezat, A. (2014). Spirituality and mental adjustment as coping strategies among women with breast cancer. Malaysian Journal of Public Health Medicine, 14(1), 1-9.

Rakrachakarn, V., Moschis, G. P., Ong, F. S., \& Shannon, R. (2013). Materialism and Life Satisfaction: The Role of Religion. Journal of Religion and Health, 54(2), 413-426. https://doi.org/10.1007/s10943-013-9794-y

Rasheed, M., Iqbal, S., \& Mustafa, F. (2018). Work-family conflict and female employees' turnover intentions. Gender in Management, 33(8), 636-653. https://doi.org/10.1108/GM-09-2017-0112

Raskin, P. M. (2006). Women, work, and family: Three studies of roles and identity among working mothers. American Behavioral Scientist, 49(10), 1354-1381. https://doi.org/10.1177/0002764206286560

Roman, C. (2019). Gendered and classed experiences of work-family conflict among lone mothers in Sweden. Community, Work and Family, 22(3), 302-318. https://doi.org/10.1080/13668803.2018.1456404

Santos, G. G., \& Cabral-Cardoso, C. (2008). Work-family culture in academia: A gendered view of work-family conflict and coping strategies. Gender in Management, 23(6), 442-457. https://doi.org/10.1108/17542410810897553

Seiger, C. P., \& Wiese, B. S. (2009). Social support from work and family domains as an antecedent or moderator of work-family conflicts? Journal of Vocational Behavior, 75(1), 26-37. https://doi.org/10.1016/j.jvb.2009.03.001 
Sim, A. K. S., \& Bujang, S. (2012). The work-family interface of the hospitality industry in Malaysia: The moderating effects of religiosity. Asian Social Science, 8(8), 139-148. https://doi.org/10.5539/ass.v8n8p139

Tafvelin, S., Keisu, B. I., \& Kvist, E. (2020). The Prevalence and Consequences of Intragroup Conflicts for Employee Well-Being in Women-Dominated Work. Human Service Organizations Management, Leadership and Governance, 44(1), 47-62. https://doi.org/10.1080/23303131.2019.1661321

Tan, L., Sim, L. K., Ng, L., Toh, H. J., \& Low, J. A. (2017). Advance Care Planning: The Attitudes and Views of a Group of Catholic Nuns in Singapore. American Journal of Hospice and Palliative Medicine, 34(1), 26-33. https://doi.org/10.1177/1049909115615563

Unterrainer, H., Lewis, A., \& Fink, A. (2014). Religious/spiritual well-being, personality and mental health: A review of results and conceptual issues. Journal of Religion and Health, 53(2), 382-392.

Van Daalen, G., Willemsen, T. M., \& Sanders, K. (2006). Reducing work-family conflict through different sources of social support. Journal of Vocational Behavior, 69(3), 462-476. https://doi.org/10.1016/j.jvb.2006.07.005

Van der Lippe, T., Jager, A., \& Kops, Y. (2006). Combination Pressure: The Paid Work-Family Balance of Men and Women in European Countries. Acta Sociologica, 49(3), 303-319.

Van Steenbergen, E. F., Ellemers, N., \& Mooijaart, A. (2007). How work and family can facilitate each other: distinct types of work-family facilitation and outcomes for women and men. Journal of Occupational Health Psychology, 12(3), 279-300. https://doi.org/10.1037/1076-8998.12.3.279

Villani, D., Sorgente, A., Iannello, P., \& Antonietti, A. (2019). The role of spirituality and religiosity in the subjective well-being of individuals with different religious status. Frontiers in Psychology, 10(JULY). https://doi.org/10.3389/fpsyg.2019.01525

Voydanoff, P. (2004). Demands and Resources on The Effects of Work Conflict and Facilitation. Journal of Marriage and Family, 66(1), 398-412. https://doi.org/10.1111/j.17413737.2004.00028.x

Wiese, B. S., \& Salmela-Aro, K. (2008). Goal conflict and facilitation as predictors of workfamily satisfaction and engagement. Journal of Vocational Behavior, 73(3), 490-497. https://doi.org/10.1016/j.jvb.2008.09.007

Yang, N., Chen, C. C., Choi, J., \& Zou, Y. (2000). Sources of work-family conflict : A Sino-U. S. comparison of the effects of work and family demands. Academy of Management Journal, 43(1), 113-123.

Zahra, G., \& Simin, H. (2011). Depression in women and its relation with well-being, individual and social factors in Iran, 2011. Procedia - Social and Behavioral Sciences, 28, 553-557. https://doi.org/10.1016/j.sbspro.2011.11.106

Zhang, M., Griffeth, R. W., \& Fried, D. D. (2012). Work-family conflict and individual consequences. Journal of Managerial Psychology, 27(7), 696-713. https://doi.org/10.1108/02683941211259520

Zotti, R., Speziale, N., \& Barra, C. (2016). On the causal effect of religiosity on life satisfaction using a propensity score matching technique. International Journal of Social Economics, 43(10), 1031-1048. https://doi.org/10.1108/IJSE-12-2014-0262 